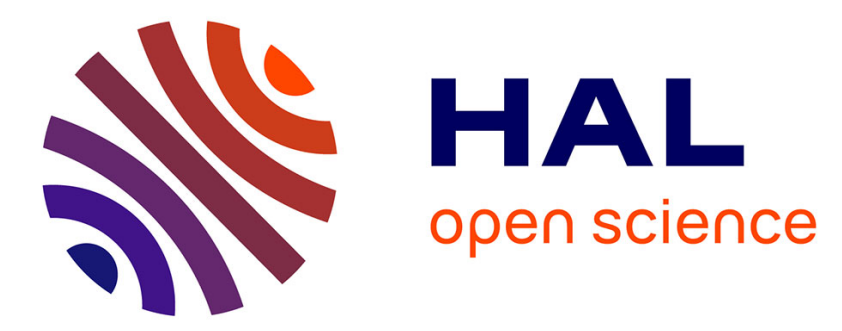

\title{
Phytoliths as paleoenvironmental indicators, West Side Middle Awash Valley, Ethiopia
}

D. Barboni, Raymonde Bonnefille, A. Alexandre, J. D. Meunier

\section{To cite this version:}

D. Barboni, Raymonde Bonnefille, A. Alexandre, J. D. Meunier. Phytoliths as paleoenvironmental indicators, West Side Middle Awash Valley, Ethiopia. Palaeogeography, Palaeoclimatology, Palaeoecology, 1999, 152 (1-2), pp.87-100. 10.1016/s0031-0182(99)00045-0 . hal-01909694

\section{HAL Id: hal-01909694 \\ https://hal.science/hal-01909694}

Submitted on 31 Oct 2018

HAL is a multi-disciplinary open access archive for the deposit and dissemination of scientific research documents, whether they are published or not. The documents may come from teaching and research institutions in France or abroad, or from public or private research centers.
L'archive ouverte pluridisciplinaire HAL, est destinée au dépôt et à la diffusion de documents scientifiques de niveau recherche, publiés ou non, émanant des établissements d'enseignement et de recherche français ou étrangers, des laboratoires publics ou privés. 


\section{Phytoliths as paleoenvironmental indicators, West Side Middle Awash Valley, Ethiopia}

Article in Palaeogeography Palaeoclimatology Palaeoecology · August 1999

DOI: 10.1016/S0031-0182(99)00045-0

CITATIONS

4 authors:

\section{Doris Barboni}

Centre Européen de Recherche et d'En..

46 PUBLICATIONS 916 CITATIONS

SEE PROFILE

Anne Alexandre

French National Centre for Scientific R...

78 PUBLICATIONS 2,269 CITATIONS

SEE PROFILE
Bonnefille Raymonde

Aix-Marseille Université

114 PUBLICATIONS $\quad 4,611$ CITATIONS

SEE PROFILE

J.D. Meunier

Aix-Marseille Université

58 PUBLICATIONS 1,810 CITATIONS

SEE PROFILE 


\title{
PALAEO
}

ELSEVIER

Palaeogeography, Palaeoclimatology, Palaeoecology 152 (1999) 87-100

\section{Phytoliths as paleoenvironmental indicators, West Side Middle Awash Valley, Ethiopia}

\author{
D. Barboni ${ }^{\mathrm{a}, *}$, R. Bonnefille ${ }^{\mathrm{a}}$, A. Alexandre ${ }^{\mathrm{b}}$, J.D. Meunier ${ }^{\mathrm{b}}$ \\ ${ }^{a}$ French Institute of Pondicherry, BP 33, 11 Saint-Louis street, Pondicherry 605001, India \\ ${ }^{b}$ C.E.R.E.G.E, Europôle Méditerranéen de l'Arbois, BP 80, 13545 Aix-en-Provence Cedex 4, France
}

Received 28 October 1997; revised version received 7 October 1998; accepted 13 January 1999

\begin{abstract}
Phytolith assemblage analysis offers the potential to refine our knowledge of paleoecosystems where grasses and sedges predominate. In this work, Holocene and Pleistocene sediments from an arid tropical region in Ethiopia have been analyzed for their phytolith content, presented as detailed counts and diagrams according to the Twiss classification. The aim is to test the usefulness of phytolith assemblages to indicate paleoenvironments at Middle Awash, where fossil pollen grains are poorly preserved in sediments that yielded abundant archaeological remains. The vegetation in the Middle Awash subdesertic valley is currently a shrub steppe dominated by $\mathrm{C} 4$ grasses adapted to arid conditions, with a narrow riparian forest limited to the Awash River. Our results show that modern surface samples, Holocene and Pleistocene sediments contain well-preserved and different phytolith assemblages, and therefore that no translocation processes from modern soil to geological strata seem to occur. Fossil records and modern assemblages are interpreted using phytolith ratios to estimate the density of the tree cover, the aridity and the proportion of $\mathrm{C} 3$ versus $\mathrm{C} 4$ grasses, as applied to phytolith assemblages from North America and West Africa. The phytolith assemblages from modern soil samples correctly reflect the proportion of trees and shrubs versus grasses, different in the riparian vegetation and the shrub steppe. Modern phytolith assemblages appear to be a mixed signature of local and regional vegetation. Phytolith analysis of the Holocene sample suggests a grassland, where the grass community is constituted by the Chloridoideae subfamily, adapted to warm and dry conditions and where C3-Pooideae cover the highlands. Phytolith analysis of the Pleistocene sample evidences grassland formation with scattered woody elements, where C4-Panicoideae grasses, adapted to warm and humid conditions dominate the grass cover. However, these conclusions need to be confirmed by more complete study on phytolith assemblages from modern vegetation from Ethiopia. (C) 1999 Elsevier Science B.V. All rights reserved.
\end{abstract}

Keywords: phytoliths; paleoenvironment; Middle Awash; Ethiopia

\section{Introduction}

Phytoliths are microscopic opal-A particles (Jones and Segnit, 1969) that precipitate in cells and/or * Corresponding author. Fax: +91-413-339534; E-mail:
instfran@ giasmd01.vsnl.net.in between cells of living plant tissues. They occur in many plant families (Piperno, 1988), but they are especially abundant, diverse and distinctive in the Poaceae (Twiss et al., 1969; Twiss, 1987, 1992). Due to this distinctiveness, phytolith analysis allows for separation between forest and grassland, C3 and $\mathrm{C} 4$ grasslands and, among the $\mathrm{C} 4$ grasslands, those 
dominated by the subfamily Chloridoideae and those by Panicoideae (Twiss, 1987; Fredlund and Tieszen, 1994, 1997; Alexandre et al., 1997). Fossil phytolith assemblages from soils and lake sediments have been used to reconstruct paleovegetation patterns, especially forest/grassland ecotones (Alexandre et al., 1997). Further, trends in grassland dynamics have been investigated through the evolution of the Poaceae associations (Kurman, 1985; Fredlund et al., 1985; Bartolome et al., 1986; Fisher et al., 1995; Fredlund and Tieszen, 1997).

This paper presents a preliminary study on phytolith assemblages, applied to paleoenvironmental reconstruction from the West Side of the Middle Awash Valley (Ethiopia), an area which is of particular interest due to its richness in archaeological and anthropological sites. This work was designated as a complementary study to fossil pollen grain analysis, which has shown that grasses were an abundant component of the vegetation in the Ethiopian Rift at least since the Pliocene (Bonnefille, 1995). Because pollen grains are poorly preserved in Middle Awash fossil sediments and because grass pollen is indistinguishable at the generic level, phytolith assemblage analysis have been tried as a new and complementary paleoecological indicator. Here we report on a pilot investigation designated to test whether samples from Holocene and Pleistocene deposits yielded phytoliths, and how they differ from the modern ones.

\section{Environmental setting of the Middle Awash}

The West Side of the Middle Awash hominid site $\left(10^{\circ} 30^{\prime} \mathrm{N}, 40^{\circ} 25^{\prime} \mathrm{E}\right)$ is located in the southern Afar Rift, straddling the Awash River (Fig. 1). At present, the Middle Awash basin structural context leads to climatic differences between the study area and the northwestern Ethiopian escarpment.

The Ethiopian plateau, between 1800 and $2500 \mathrm{~m}$ of altitude, is characterized by annual rainfall higher than $1400 \mathrm{~mm} / \mathrm{yr}$, and by a mean annual temperature of about $16^{\circ} \mathrm{C}$ (F.A.O., 1965). It is the domain of afromontane forest with scattered Juniperus procera forest on the drier slopes of the escarpment up to $3300 \mathrm{~m}$ of elevation (Friis, 1986). Above the forest altitudinal zone, montane grasslands include grasses belonging to the Pooideae (e.g. Poa, Agrostis, Avena) and Panicoideae (e.g. Andropogon, Pennisetum) subfamilies, Cyperaceae and scattered shrubs and trees (Sermolli, 1957).

On the rift escarpment of the northwestern Ethiopian plateau, between 1500 and $800 \mathrm{~m}$, mean annual rainfall is mostly between 500 and $800 \mathrm{~mm} / \mathrm{yr}$ and the mean annual temperature about $26^{\circ} \mathrm{C}$. Evergreen and semi-evergreen bushland and thicket occur on steep slopes, with trees and succulents. Grasses belong to subfamilies Panicoideae (Chrysopogon, Cenchrus, Brachiaria), Arundinoideae (Aristida) and Chloridoideae (Chloris, Schmidtia) (Gillett, 1941; Gilliland, 1952; Sermolli, 1957; White, 1983).

In the Awash valley, below $500 \mathrm{~m}$, rainfall ranges from 250 to $500 \mathrm{~mm} / \mathrm{yr}$, and the mean annual temperature is about $30^{\circ} \mathrm{C}$. The climate is characterized by two rainy seasons, respectively, in March-April and July-August-September (Delliquadri, 1958). With a mean annual evapotranspiration potential above $1055 \mathrm{~mm}$, the region is considered arid. Acacia-Commiphora scattered bushland, thicket and the shrub steppe occur here. Grass cover of the steppe is dominated by $\mathrm{C} 4$ grasses belonging to the Chloridoideae subfamily (e.g. Chloris and Cynodon) and, in the small temporary pools, by the Panicoideae subfamily (e.g. Chrysopogon, Cenchrus, Andropogon) (Gillett, 1941; Gilliland, 1952; Sermolli, 1957; White, 1983).

The Awash River rises on the northwestern plateau of central Ethiopia at $3000 \mathrm{~m}$ of altitude, and crosses these different climatic and vegetation zones in its descent. Its riparian vegetation, restricted to a narrow riverine forest zone in the Middle Awash Valley, is mostly dominated by shrubs, trees such as Terminalia, Ficus, Tamarix, Salvadora and climbers (Bonnefille et al., 1987). The herbaceous layer is mostly constituted by $\mathrm{C} 4$ grasses, such as Chloridoideae (Chloris, Lintonia, Cynodon, Sporobolus) and Panicoideae (Pennisetum, Sorghum) and also by C3 grasses belonging to the Arundinoideae subfamily, such as Phragmites (Sermolli, 1957). Table 1 gives the list of the grass subfamilies and dominant genera for the western Middle Awash Valley reported from the literature. Attribution to the $\mathrm{C} 3$ or C4 photosynthetic pathway is compiled from Smith and Brown (1973), Brown (1977) and Watson et al. (1985). 


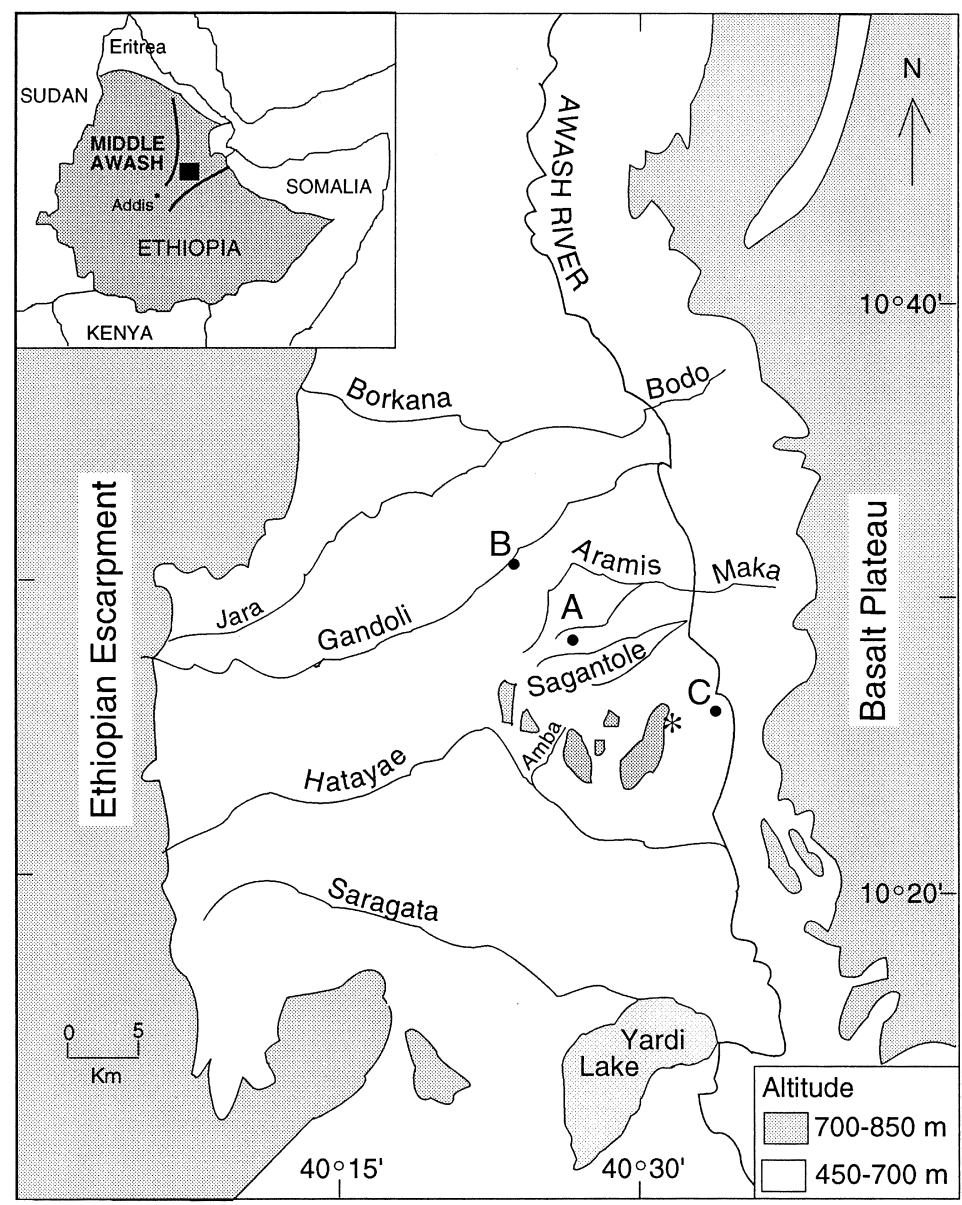

Fig. 1. Location of the samples in the Middle Awash Valley (Ethiopia). $A=$ surface soil sample MA94-103; $B=$ stream mud sample MA94-106; $C=$ surface soil sample MA94-101; * = Aduma fossil site.

\section{Field and laboratory methods}

\subsection{Field sampling}

Sediment samples for pollen and phytolith analysis were collected in the Middle Awash valley during the 1994 field season of the Middle Awash Project (White et al., 1994). Five samples were analyzed for this preliminary study, one from Holocene strata, one from Pleistocene, and three from modern surface soil (Table 2). The sampling method for the modern soil consists of collecting at more than twenty spots the upper one $\mathrm{cm}$ of the litter deposited at the soil surface. The individual sub-samples collected at random over an area of about hundred square meters are mixed together. This sampling method provides data on the average modern pollen rain over a few years that correctly reflect the different vegetation types encountered in the lower Awash valley (Bonnefille et al., 1987), and more specifically in the Ethiopian plateau (Bonnefille et al., 1993). The first modern sample (MA94-103, 10 $28^{\prime} \mathrm{N}, 40^{\circ} 27^{\prime} \mathrm{E}$ ) (A, Fig. 1), collected under Acacia trees near the course of the Aramis stream, is from the subdesertic steppe. The second modern sample (MA94-106, $10^{\circ} 31^{\prime} \mathrm{N}$, $40^{\circ} 26^{\prime} \mathrm{E}$ ) (B, Fig. 1), consists of the mud collected after one flood of the Ganduli River, a tributary of the Awash River. The third modern sample (MA94$101,10^{\circ} 27^{\prime} \mathrm{N}, 40^{\circ} 30^{\prime} \mathrm{E}$ ) (C, Fig. 1), was collected in a swampy area surrounded by trees at the margin of 
Table 1

Dominant genera and subfamilies among the modern grasses of the Awash valley, Ethiopia after Sermolli (1957), Gillett (1941), Gilliland (1952); C3 and C4 attribution after Smith and Brown (1973), Brown (1977) and Watson et al. (1985)

\begin{tabular}{lll}
\hline Subfamily & Genus & $\mathrm{C} 3 / \mathrm{C} 4$ \\
\hline Pooideae & Poa & $\mathrm{C} 3$ \\
& Agrostis & $\mathrm{C} 3$ \\
Avena & $\mathrm{C} 3$ \\
Chloridoideae & Chloris & $\mathrm{C} 4$ \\
& Cynodon & $\mathrm{C} 4$ \\
& Lintonia & $\mathrm{C} 4$ \\
Schmidtia & $\mathrm{C} 4$ \\
Panicoideae & Sporobolus & $\mathrm{C} 4$ \\
& Andropogon & $\mathrm{C} 4$ \\
& Brachiaria & $\mathrm{C} 4$ \\
& Cenchrus & $\mathrm{C} 4$ \\
& Chrysopogon & $\mathrm{C} 4$ \\
& Pennisetum & $\mathrm{C} 4$ \\
Sorghum & $\mathrm{C} 4$ \\
& Phragmites & $\mathrm{C} 3$ \\
& Aristida & $\mathrm{C} 4$ \\
\hline
\end{tabular}

the riparian forest, on the west bank of the Awash river, near Aduma.

The geological samples were taken from outcrops at the Aduma archaeological excavation (Fig. 1). The Pleistocene sample MA94-097 was collected from the second shell bed which contains Middle Stone Age archaeological artefacts in the 'Ardu' beds, exposed at the A4 archaeological trench (A. Brooks, pers. commun.). The sample MA94-098 comes from the black montmorillonite layer, lying on the top of the beds at the same locality. Its age is most probably Holocene.

\subsection{Chemical treatment}

Approximately $10 \mathrm{~g}$ of sediment sample was used for each phytolith extraction. The phytoliths were extracted by dissolution of carbonates using acetic acid buffered at $\mathrm{pH} 3$, oxidation of the organic matter, using $30 \%$ hydrogen peroxide at $90^{\circ} \mathrm{C}$ until reaction subsides, and mechanical removal of clays. Densimetric separation of phytoliths from residue is achieved by separation in a zinc bromide solution with a density of 2.3 (Kelly, 1990). This light fraction, including opal phytoliths, diatoms and volcanic ashes, was mounted on microscope slides, using glycerin as a mounting medium. Microscopic observations were done at $\times 600$ magnification.

\section{Phytolith classification and counting}

The extracted phytoliths were counted and classified according to the classification of Twiss (Twiss et al., 1969; Twiss, 1992), improved and completed by phytolith shape descriptions of Mulholland (1986, 1989), Mulholland and Rapp (1992) and Fredlund and Tieszen (1994). The different morphotypes identified in the Middle Awash samples are illustrated in Plate I. Short-cell phytoliths from grass epidermis are related to three Poaceae subfamilies (Metcalfe, 1960; Brown, 1984; Twiss, 1987; Mulholland, 1989). The rondel and rectangle morphotypes fol-

Table 2

List of Middle Awash samples treated for phytolith analysis

\begin{tabular}{|c|c|c|c|}
\hline Samples & Sites & Coordinates or stratigraphic position & Nature of samples \\
\hline \multicolumn{4}{|l|}{ Modern } \\
\hline MA94-103 & Aramis site, subdesertic steppe & $10^{\circ} 28^{\prime} \mathrm{N}, 40^{\circ} 27^{\prime} \mathrm{E}$, altitude $500 \mathrm{~m}$ & surface litter soil \\
\hline MA94-106 & Ganduli river bank & $10^{\circ} 31^{\prime} \mathrm{N}, 40^{\circ} 26^{\prime} \mathrm{E}$, altitude $600 \mathrm{~m}$ & stream mud \\
\hline MA94-101 & Aduma site, Awash riparian forest & $10^{\circ} 27^{\prime} \mathrm{N}, 40^{\circ} 30^{\prime} \mathrm{E}$, altitude $500 \mathrm{~m}$ & surface litter soil \\
\hline \multicolumn{4}{|l|}{ Holocene } \\
\hline MA94-098 & $\begin{array}{l}\text { Aduma, section A4 } \\
\text { (archaeological trench) }\end{array}$ & top geological layer above Ardu beds & black clay (vertisol) with plant remains \\
\hline \multicolumn{4}{|l|}{ Pleistocene } \\
\hline MA94-097 & $\begin{array}{l}\text { Aduma, section A4 } \\
\text { (archaeological trench) }\end{array}$ & Middle Stone Age archaeological level & second shell bed with fish bones \\
\hline
\end{tabular}


low the definition of Mulholland (1989) and belong to the pooid type (Twiss et al., 1969). They occur dominantly in the subfamily Pooideae, which are C3 grasses abundant in cool, moist climates and at high elevations where available soil moisture is high during the growing season (Tieszen et al., 1979; Livingstone and Clayton, 1980). According to the same authors, the saddle morphotype, which belongs to the chloridoid type, is produced in high proportion by the Chloridoideae, represented by $\mathrm{C} 4$ grasses adapted to warm and dry climatic or edaphic conditions. The cross and dumbbell morphotypes belong to the panicoid type and occur dominantly in the subfamily Panicoideae, mainly represented by warm-season $\mathrm{C} 4$ grasses adapted to high available soil moisture (Tieszen et al., 1979; Twiss, 1980). It should be noted that pooid phytoliths have also been described in the intercostal zones of the epidermis of Chloridoideae and Panicoideae, but are produced in small amount (Brown, 1984; Mulholland, 1989).

Among the other grass subfamilies, Bambusoideae and Arundinoideae produce the same general morphotypes as discussed previously; no morphotypes are distinctive to the subfamily level (Metcalfe, 1960; Brown, 1984; Mulholland, 1986, 1989; Ollendorf et al., 1988). Morphotypes elongate smooth, elongate sinuous, point and fan-shaped are phytoliths from epidermis long-cells and bulliform-cells of grasses. They are without taxonomic significance in the adopted classification (Twiss et al., 1969).

This classification of phytolith shapes has been criticized because multiplicity and redundancy of many grass morphotypes prevent the attribution of phytoliths to species or genus (Rovner, 1971; Brown, 1984; Mulholland, 1989). Because several shapes of phytolith occur in many grass taxa, a single phytolith morphotype cannot belong to a single grass species. But on the other hand, a phytolith assemblage can indicate the dominant subfamily constituting the grass association (Fredlund and Tieszen, 1994). The phytolith assemblages are also helpful to distinguish $\mathrm{C} 3$ from $\mathrm{C} 4$ grasslands and, among the $\mathrm{C} 4$ grasslands those dominated by Chloridoideae from those dominated by Panicoideae (Fredlund and Tieszen, 1994, 1997). Dry and wet C4 grasslands of West Africa were also well discriminated by phytolith assemblages using Twiss classification (Alexandre et al., 1997).
Non-Poaceae families also produce characteristic morphotypes. The cone-shape morphotype is attributed to the Cyperaceae (sedge) (Le Cohu, 1973; Ollendorf, 1987; Piperno, 1988) and the circular crenate to the Palmae (Piperno, 1988). The circular rugose morphotype, produced by the sclerenchym of ligneous dicotyledon (Geis, 1973; Scurfield et al., 1974; Welle, 1976; Laroche, 1976; Bozarth, 1992) is attributed to woody elements (Alexandre et al., 1997). The corkcell-like morphotype may not have any taxonomic significance because different families produce it (Ellis, 1979). These morphotypes have been identified in the phytolith assemblages of the Middle Awash samples (Plate I).

SEM photos of East African grass epidermis (Palmer and Tucker, 1981, 1983; Palmer et al., 1985; Palmer and Gerbeth-Jones, 1986) were consulted to check the applicability of Twiss classification to the grasses from the Middle Awash region. We found that East African Pooideae are rich in rectangles and rondels, Chloridoideae are characterized by abundance of saddles and Panicoideae by the abundance of crosses and dumbbells, which fits the usual pattern (Twiss et al., 1969). However, there are some exceptions. Sporobolus, frequent on riverbanks and largely represented in mud flats surrounding East African lakes (Menaut, 1983) as well as Phragmites, abundant nearby the Awash River (Sermolli, 1957), do not have a phytolith production that corresponds to the above classification. Actually, Sporobolus, which is a C4-Chloridoideae grass, produces the pooid type, and Phragmites, which is a C3-Arundinoideae species, produces the chloridoid type. These exceptions will be taken into account while discussing the results.

\section{Results}

Phytoliths were recovered in Pleistocene, Holocene and all three of the modern samples that were processed. The number of phytoliths counted ranged from 750 up to more than 1800 per slide in order to discuss at least 200 short-cell morphotypes for each sample. Phytoliths with unrecognizable shape were counted and listed in the unidentified category. The percentages of pooid, chloridoid and panicoid phytoliths are calculated on the sum of the 
PLATE I
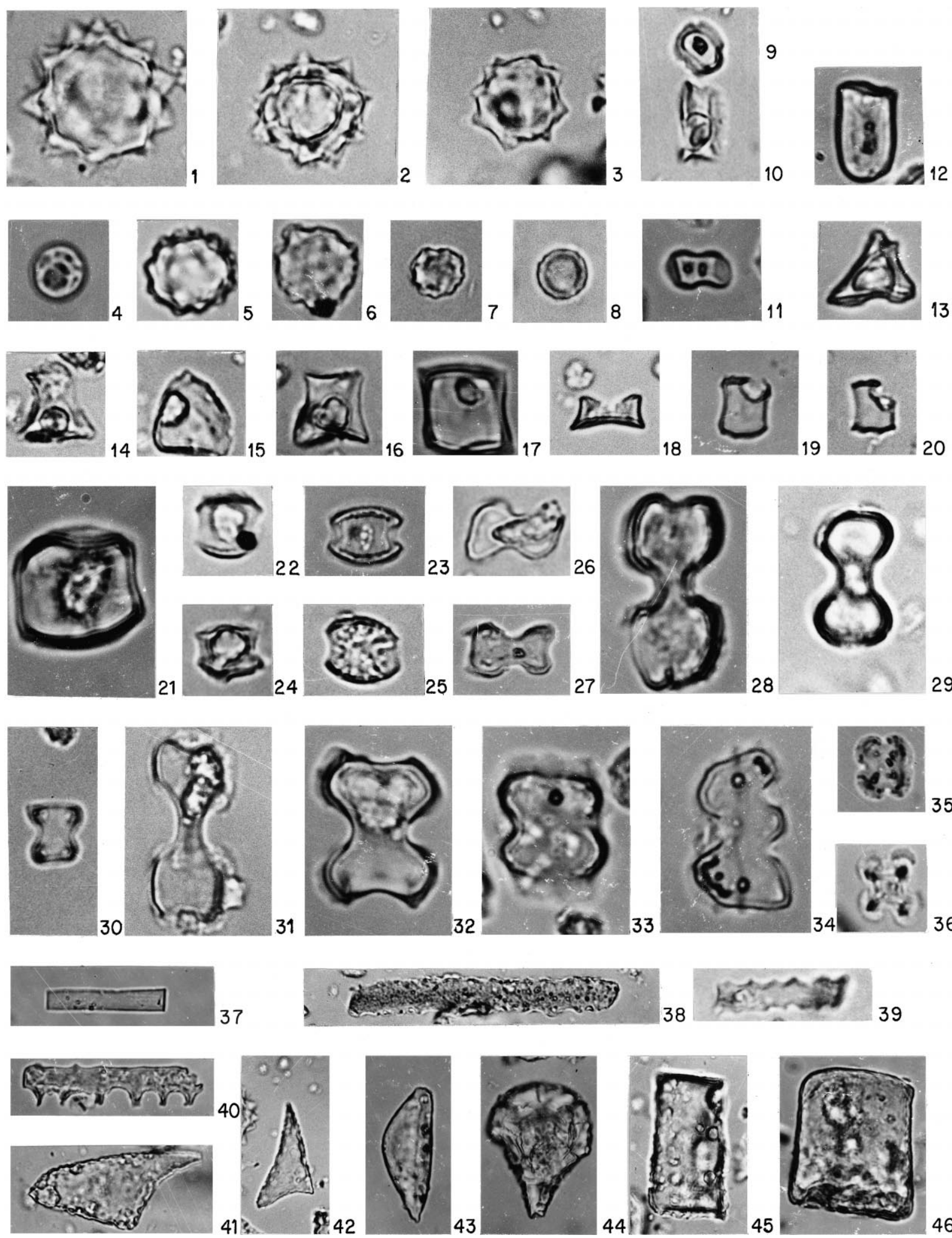
Table 3

Detailed counts of Poaceae and other plant phytoliths, recovered from modern and fossil samples from the western Middle Awash valley (Ethiopia)

\begin{tabular}{|c|c|c|c|c|c|c|}
\hline & \multirow[t]{2}{*}{ Morphotypes } & \multicolumn{3}{|l|}{ Surface soil } & \multirow{2}{*}{$\frac{\text { Holocene }}{\text { MA94-098 }}$} & \multirow{2}{*}{$\frac{\text { Pleistocene }}{\text { MA94-097 }}$} \\
\hline & & MA94-103 & MA94-106 & MA94-101 & & \\
\hline \multicolumn{7}{|c|}{ Poaceae short-cell phytoliths } \\
\hline & rectangle & 22 & 45 & 62 & 72 & 56 \\
\hline & rondel & 126 & 43 & 78 & 67 & 95 \\
\hline & saddle & 86 & 36 & 91 & 28 & 24 \\
\hline & dumbbell & 66 & 126 & 132 & 39 & 66 \\
\hline & cross & 23 & 41 & 29 & 5 & 13 \\
\hline & $\sum$ short-cells & 323 & 291 & 392 & 211 & 254 \\
\hline \multicolumn{7}{|c|}{ Poaceae long-cell phytoliths } \\
\hline & elongate smooth & 57 & 62 & 42 & 1332 & 75 \\
\hline & elongate sinuous & 90 & 55 & 52 & 70 & 36 \\
\hline & fan shaped & 95 & 91 & 106 & 97 & 90 \\
\hline & point shaped & 69 & 56 & 69 & 30 & 108 \\
\hline & $\sum$ long-cells & 311 & 264 & 269 & 1529 & 309 \\
\hline Ligneous & circular rugose & 54 & 101 & 435 & 33 & 100 \\
\hline Palmeae & circular crenate & 11 & 5 & 0 & 2 & 1 \\
\hline Cyperaceae & cone shape & 0 & 12 & 13 & 3 & 5 \\
\hline \multirow[t]{4}{*}{ All plants } & corkcell like & 156 & 83 & 198 & 78 & 64 \\
\hline & $\sum$ non-Poaceae & 221 & 201 & 646 & 116 & 170 \\
\hline & unidentified & 17 & 14 & 27 & 19 & 23 \\
\hline & total & 872 & 770 & 1334 & 1875 & 756 \\
\hline
\end{tabular}

short-cell morphotypes alone ( $\sum$ short cell), to emphasize their variability in each sample. Percentages of Poaceae long-cell morphotypes and non-Poaceae morphotypes are presented in percent of the total

\section{PLATE I}

Non-Poaceae phytoliths (1-8) and Poaceae phytoliths (9-46). Phytoliths 1-36, ×1000; phytoliths 37-46, ×500.

1-3. Circular crenate (Palmae type).

4. Corkcell like (all plants).

5-8. Circular rugose (ligneous dicotyledons type).

9-17. Pooid type.

9-10. Rondel with circular base and circular flat top

11-12. Rondel with oblong base and top.

13-16. Rondel with circular base and ridge top.

17. Rectangle.

18-25. Chloridoid type: saddle.

26-36. Panicoid type.

26-34. Dumbbell.

35-36. Cross.

37-40. Elongate.

41-43. Point-shaped.

44-46. Fan-shaped. sum of phytoliths (unidentified category excluded). The detailed counts are provided in Table 3 . The relative percentages of the modern and fossil phytolith assemblages are presented in a pollen-like diagram in Fig. 2.

Dissolution features that could indicate selective destruction (Fredlund and Tieszen, 1997) have not been observed in the modern and in the Pleistocene samples. However, the elongate morphotypes of the Holocene sample presented particularly corroded surfaces.

\subsection{Modern phytolith assemblages}

In the modern assemblages, there are about $2 \%$ of unidentified taxa. The Cyperaceae (cone-shape) are not abundant (less than $2 \%$ ), even in the locally wet environments such as the riparian forest of Awash. They are absent from the banks of the Ganduli, which are not locally wet for more than a few days at a time. A low representation of Cyperaceae is expected due to the fact that this morphotype is 


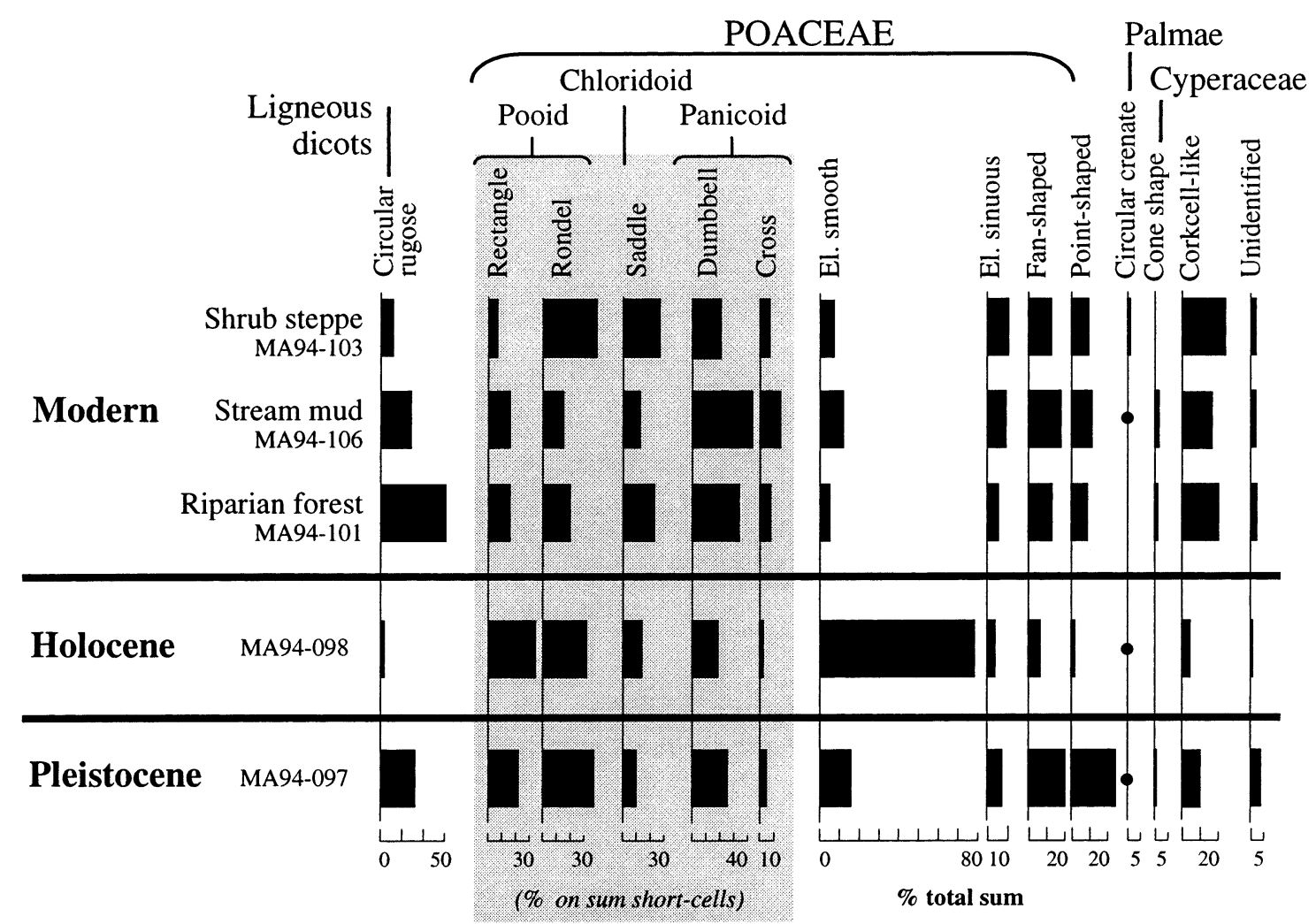

Fig. 2. Phytolith percentage diagram of modern and fossil samples from the Middle Awash anthropological site, Ethiopia.

highly subjected to dissolution, fragmentation and weathering processes (Alexandre et al., 1997). The Palmae (circular crenate) morphotypes account for less than $2 \%$. Palm trees are not present in the area, but in the Lower Awash Valley. The corkcell-like morphotype is more abundant in the steppe (18\%) than in the Awash riparian forest sample (15\%) and the Ganduli mud (11\%).

The steppe phytolith assemblage is characterized by a low proportion of the ligneous dicotyledon morphotype $(6 \%)$ and a high content of Poaceae phytoliths (more than $65 \%$ of the total sum). Among the Poaceae phytoliths, rondels represent $39 \%$, rectangles $7 \%$, dumbbells plus crosses $27 \%$ and saddles $27 \%$ of the short-cell sum (Fig. 2). The long-cell phytoliths represent $35 \%$ of the total phytolith assemblage. The stream mud of Ganduli presents a phytolith assemblage where ligneous dicotyledon phytoliths are more abundant than in the steppe (13\%). Poaceae morphotypes account for $73 \%$.
Among the short-cell Poaceae phytoliths, rectangles and rondels account for $16 \%$ and $15 \%$, saddles for $12 \%$, dumbbells plus crosses morphotypes for $57 \%$. Long-cell phytoliths represent $35 \%$ of the total assemblage. The Awash riparian forest is characterized by a phytolith assemblage with higher amount of ligneous dicotyledon morphotypes (33\%) and relative low amount of Poaceae morphotypes (50\%) compared to the shrub steppe and the mud. Among the short-cell Poaceae phytoliths, rectangles account for $16 \%$, rondels for $20 \%$, saddles for $23 \%$ and crosses plus dumbbells for $41 \%$. Long-cell phytoliths represent $20 \%$ of the total phytolith sum.

\subsection{Fossil phytolith assemblages}

The Holocene assemblage is characterized by a low content of ligneous dicotyledons morphotype (less than $2 \%$ ) and by $93 \%$ of Poaceae phytoliths, dominated by the elongate smooth morpho- 
type $(71 \%)$. Among the short-cell phytoliths, rectangles account for $34 \%$, rondels for $32 \%$, saddles for $13 \%$, and dumbbells plus crosses for $21 \%$. The corkcell morphotypes represents $4 \%$ of the total assemblage. Cyperaceae and Palmae are present.

The Pleistocene phytolith assemblage is characterized by $75 \%$ of Poaceae morphotypes and $13 \%$ of dicotyledon morphotypes. Among the short-cell Poaceae phytoliths, rectangles account for $22 \%$, rondels for about $38 \%$, saddles for $9 \%$ and dumbbells plus crosses morphotypes for $31 \%$. Elongated, fan and point-shaped have high value of $41 \%$. Undetermined phytoliths represent $3 \%$ of the total assemblage. The amount of corkcell-like morphotype in this sample is about $8 \%$, and Cyperaceae and Palmae morphotypes account for less than $1 \%$.

Modern and fossil phytolith assemblages present noticeable differences in their composition, which do provide evidence that there is no translocation of phytoliths from the surface soil to the geological layers. Consequently, phytolith assemblages can be considered as potential tools for reconstruction of paleoenvironments at Middle Awash.

\section{Interpretation and discussion}

In order to interpret phytolith assemblages, three indices have been defined by authors whose studies were done on grasses of American Great Plains (Twiss, 1992) and West African regions (DiesterHaas et al., 1973; Alexandre et al., 1997). These indices are applied to modern phytolith assemblages in an attempt to calibrate the phytolith response of the local vegetation against the climatic and/or edaphic conditions prevailing nowadays in the subdesertic Middle Awash Valley. By comparison with the results obtained for the modern samples, an interpretation of the fossil assemblages can be made.

\subsection{Modern phytolith assemblages and physiognomic aspect of the vegetation}

\subsubsection{Density of woody elements}

The first index, defined as the $\mathrm{D} / \mathrm{P}$ index, is the ratio of the ligneous dicotyledons morphotype (circular rugose) versus the Poaceae morphotypes (i.e. sum of pooid, chloridoid, panicoid, point and fan shaped) (Fig. 3). It has been used to estimate the density of woody elements in different types

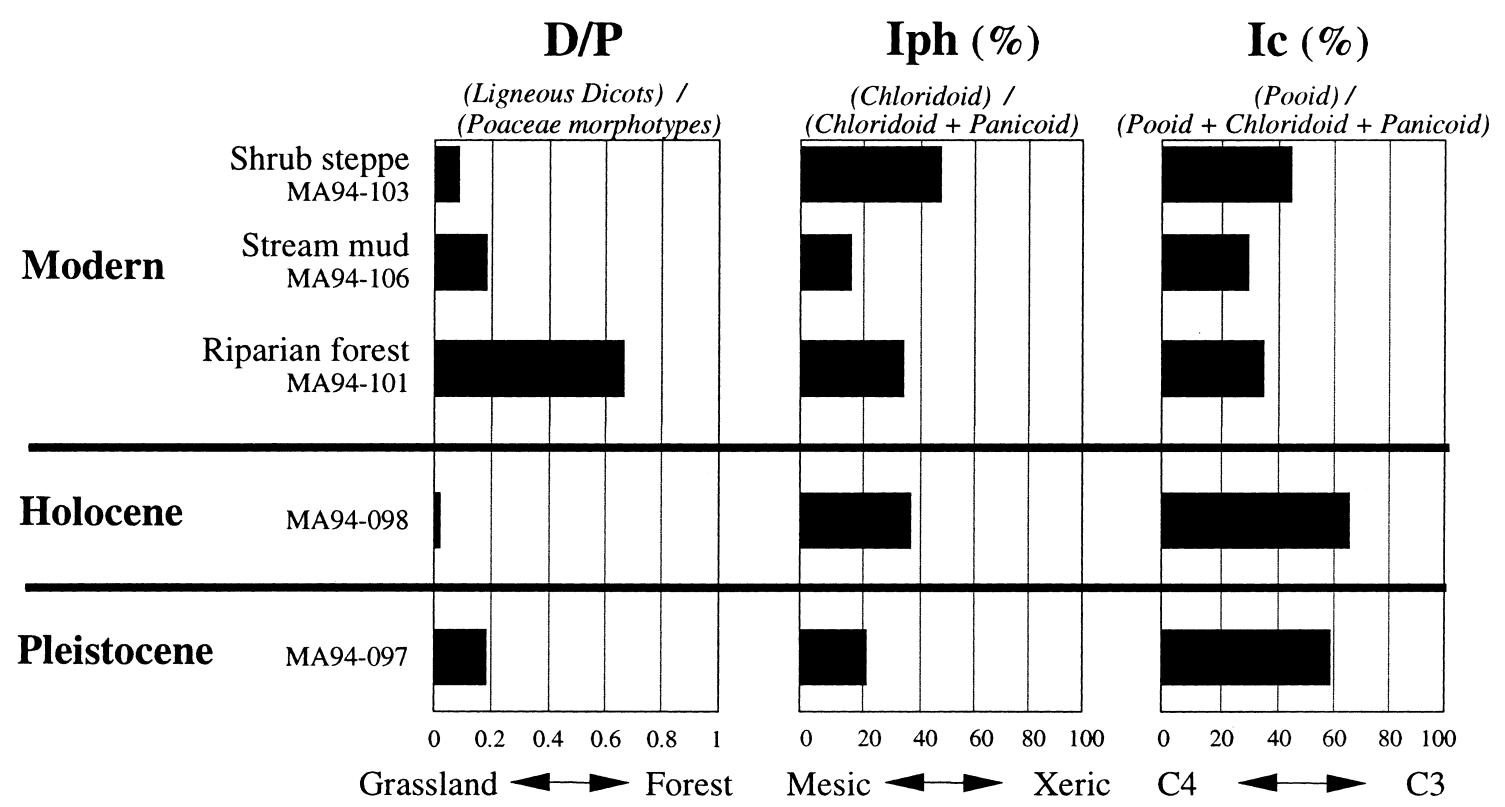

Fig. 3. Three indices $\left[\mathrm{D} / \mathrm{P}=\right.$ Tree cover density index (Alexandre et al., 1997); $I_{\mathrm{ph}}(\%)=$ aridity index (Diester-Haas et al., 1973); and $I_{\mathrm{c}}(\%)=$ climatic index (Twiss, 1987)] applied on modern and fossil samples from the Middle Awash anthropological site, Ethiopia. 
of grass savannas between $15^{\circ} \mathrm{N}$ and $4^{\circ} \mathrm{S}$ in West Africa (Alexandre et al., 1997). In modern samples, a value of 7 was found for the semi-evergreen forest in Congo, whereas values lower than 1 characterized savannas with abundant grass cover in Senegal. In fossil Holocene sediments from Lake Sinnda (Congo), remarkably high $\mathrm{D} / \mathrm{P}$ values (greater that 150 ) were found associated with high proportion of arboreal pollen, evidencing equatorial dense humid forest. In the present study at Middle Awash, $\mathrm{D} / \mathrm{P}$ of the shrub steppe, the Ganduli stream and the margin of the riparian forest are, respectively, $0.1,0.2$ and 0.7 (Fig. 3). These values correspond well with the field observations. Indeed, trees and shrubs are scarce in the shrub steppe and along the Ganduli stream, and more abundant near the Awash riparian forest. Compared to those from West Africa, the $\mathrm{D} / \mathrm{P}$ values clearly indicate that grasses dominate the vegetation cover at Middle Awash (Fig. 3). The $\mathrm{D} / \mathrm{P}$ value for the riparian forest is still much lower than the one obtained for rainforest proper in Congo, where the tree cover is dense and stratified. We assume that the $\mathrm{D} / \mathrm{P}$ would be a reliable index to estimate the density of trees and shrubs in different vegetation types in Africa. However, this conclusion would need to be confirmed by additional studies on phytolith assemblages from modern vegetation in Ethiopia.

\subsubsection{Adaptation to aridity}

The second index, first used to appreciate humidity-aridity tendencies in marine cores (DiesterHaas et al., 1973), is the ratio of chloridoid versus total chloridoid plus panicoid phytoliths (Twiss, 1992). It expresses the percentage of Chloridoideae among the $\mathrm{C} 4$ grasses. High $I_{\mathrm{ph}}$ values suggest grasslands dominated by Chloridoideae, i.e. xerophitic grasses, and hence prevalence of dry climatic conditions. Conversely, low $I_{\mathrm{ph}}$ values indicate associations in which Panicoideae, i.e. mesophytic grasses dominate, suggesting humid climatic and/or high available soil moisture. In West Africa an application of this index under the name $I_{\mathrm{ph}}$ (Phytolith Index), shows that a boundary value of $30 \%$ distinguishes tall-grass savannas of the humid Sudanian zone $\left(I_{\mathrm{ph}}<30 \%\right)$, from the short-grass savannas of the arid Sahelian region in Senegal $\left(I_{\mathrm{ph}}>30 \%\right)$ (Alexandre et al., 1997).
$I_{\mathrm{ph}}$ values of the assemblages collected in the shrub steppe, in the stream mud and at the margin of the Awash riparian forest are, respectively, 49, 18 and 36\% (Fig. 3). The highest $I_{\mathrm{ph}}$ values are for the steppe and the riparian forest, while the lowest is for the mud. This is consistent with the fact that Chloridoideae dominate in the subdesertic steppe and at the margin of the riparian forest, while Panicoideae are abundant near the streams and temporary pools. However, the low value registered in the Ganduli sample may also be explained by panicoid phytoliths input from the tall-grasses found upstream the Ganduli river at the foothills of the Ethiopian escarpment (Fig. 1). The $I_{\mathrm{ph}}$ value for the steppe (49\%) is higher than the minima value of $30 \%$ that characterizes dry grasslands in Senegal (Alexandre et al., 1997). It does correspond well with more arid conditions prevailing in East Africa. The $I_{\mathrm{ph}}$ value obtained for the riparian forest is also greater than $30 \%$. We postulate that it does not reflect the local edaphic conditions of the riparian forest itself, but fits the general climate of the region. However, Phragmites, a C3-Arundinoideae grass, which is present in the swampy areas along the riversides, and which produces the chloridoid type phytolith, may have contributed to the phytolith assemblage, thus resulting in an overestimation of the aridity.

Although $I_{\mathrm{ph}}$ values of the Middle Awash modern samples fit the general conclusions based on samples from West Africa (Alexandre et al., 1997), a more extensive study on modern phytolith assemblages under different local conditions is necessary to fully assess the climatic interpretation of the phytolith index in the arid East African Rift.

\subsubsection{Climatic index}

Twiss $(1987,1992)$ defined a climatic index $\left(I_{\mathrm{c}}\right)$ to estimate the relative proportion of $\mathrm{C} 3$ grasses present in the American Great Plains. It is the ratio of pooid versus pooid plus chloridoid plus panicoid types. High $I_{\mathrm{c}}$ values suggest an abundance of Pooideae, and hence an abundance of $\mathrm{C} 3$ grasses. Abundance of C3-Pooideae characterizes high latitudes (Twiss, 1992, fig. 6.2) and high altitudes in the tropics (Tieszen et al., 1979; Livingstone and Clayton, 1980). Consequently high $I_{\mathrm{c}}$ values suggest cool climate. Indeed, modern phytolith assemblages from the North American Great Plains show $I_{c}$ values 
greater than $70 \%$ for northern C3-Pooideae-dominated grasslands, whereas southern $\mathrm{C} 4$-dominated grasslands show values of about 30\% (calculated from Fredlund and Tieszen, 1994).

In the three modern samples collected in the Middle Awash Valley, the pooid type occurred at frequency of more than $30 \%$. The surprisingly high $I_{\mathrm{c}}$ values would indicate the presence of Pooideae grasses. But their occurrence at Middle Awash is not consistent either with the tropical arid conditions (Twiss, 1992), or with their location in the lowlands or with the description of the vegetation (Sermolli, 1957). Inflorescence materials of non-Pooideae grasses may also produce the pooid morphotype in small amounts (Mulholland, 1989). However, statistical analysis carried out on phytolith assemblages from North American great Plains has shown a good correspondence between proportion of pooid morphotypes and representation of the Pooideae subfamily (Fredlund and Tieszen, 1994, 1997). The relatively high $I_{\mathrm{c}}$ value of the riparian forest (36\%) could be explained by the presence of Sporobolus, which produces the pooid type though it belongs to the Chloridoideae subfamily. However, it is more difficult to explain the high $I_{\mathrm{c}}$ values for the steppe $(46 \%)$ and for the mud (30\%) where Sporobolus is absent from the local vegetation. If no other grasses at Middle Awash Valley produce pooid phytoliths (Palmer and Tucker, 1981, 1983; Palmer et al., 1985; Palmer and Gerbeth-Jones, 1986), we must then consider that non-local source areas contribute to the phytolith assemblages of the modern samples at Middle Awash.

Various phytolith dispersal processes can be considered. Fires are considered to be important regional vectors of phytolith transportation and deposition (Twiss et al., 1969; Twiss, 1983, 1987), as well as aeolian processes, herbivory, fluvial and colluvial erosion (Clark, 1988; Fredlund and Tieszen, 1994). In North American Great Plains, extra-local and regional source areas have been estimated to be responsible for 30-70\% of the annual phytolith budget for grassland soils (Fredlund and Tieszen, 1994). At Middle Awash, the geomorphic setting and the distribution of rainfall over the year, as well as the main winds must be considered as potential processes for phytolith dispersion and deposition in the valley. The main winds blow eastward from the Ethiopian highlands and runoff is important in this arid region where rainfall on the escarpment occurs at high rates but over a short period. Although regional phytolith input from the Ethiopian plateau is not so obviously evidenced by the $\mathrm{D} / \mathrm{P}$ and $I_{\mathrm{ph}}$ indices, the presence of Palmae phytolith, though Palm trees are absent in the local vegetation, also suggests that extra-local sources supply modern phytolith assemblages. It is also interesting to note that the pooid type was not found in modern phytolith assemblages from West Africa, where highlands as potential source areas of this phytolith type do not exist (Alexandre et al., 1997). In this study, $I_{c}$ values can be more likely explained by high-elevation contributions by wind or runoff. We assume that phytolith assemblages include C3-Pooideae signal from highland vegetation, mixed with local grass composition of the subdesertic steppe.

Finally, our investigation of the modern phytolith assemblages shows that the two local environments, the subdesertic steppe and the riparian forest are well discriminated by the $\mathrm{D} / \mathrm{P}$ index, which values are in good agreement with the local shrub and tree cover densities. The two other indices are, however, not fitting exactly the local vegetation. The $I_{\mathrm{ph}}$ values are in agreement with the aridity of the local grass associations, taking into account potential bias resulting from the presence of Phragmites. The significance of the climatic index appears more likely interpreted by a mixture of phytoliths from regional and local source areas. Additional investigation of phytolith assemblages collected in a soil surface developed under highland C3-Pooideae grasslands would allow a better interpretation of modern phytolith assemblages in the Middle Awash Valley. Nevertheless, extra-local contributions may influence $\mathrm{D} / \mathrm{P}$ and $I_{\mathrm{ph}}$ indices but do not control them.

\subsection{Fossil assemblages}

The interpretation of the fossil assemblages must take into account two facts: (1) Phytolith index $I_{\mathrm{ph}}$ can overestimate the aridity of a lacustrine or riparian fossil sample if Phragmites was abundant in the local vegetation. (2) Climatic index $I_{\mathrm{c}}$ for this area evidences the vegetation signature on both regional and local scale.

The phytolith assemblage related to the Holocene sample is clearly characterized by a very high pro- 
portion $(70 \%)$ of corroded elongate smooth morphotypes, which has no equivalence in the modern samples. The same phenomena has been observed in four samples of Pleistocene loess sediment from the Central Great Plains of North America (Twiss, 1987). Corroded particles may indicate chemical and/or mechanical erosive action by various agents such as running water or wind. The very low $\mathrm{D} / \mathrm{P}$ value for the Holocene sample implies that local vegetation was a grassland. The high $I_{\mathrm{ph}}$ value (39\%) indicates a high contribution of phytoliths from C4-Chloridoideae grasses, although non-Chloridoideae species such as Phragmites may have contributed to the assemblage. The high $I_{\mathrm{c}}$ value $(66 \%)$ implies a significant contribution of phytoliths from C3-Pooideae, although the presence of non-Pooideae species such as Sporobolus may have contributed to the assemblage. Since Chloridoideae and Pooideae cannot be found under the same ecological conditions in East Africa (Livingstone and Clayton, 1980), phytoliths of the Holocene sample must have been brought in from different areas. This phytolith assemblage seems to record local grassland rich in Chloridoideae grasses, adapted to a dry environment, and C3-Pooideae grasses would have covered the Ethiopian Plateau. Aberrant 'co-existence' of Chloridoideae and Pooideae as well as abundance of corroded particles in the Holocene assemblage imply potential transport and long-distance phytolith input.

The phytolith assemblage related to the Pleistocene sample, contemporaneous with Middle Stone Age archaeological artefacts, shows a $\mathrm{D} / \mathrm{P}$ value of 0.2 . Following the same arguments as those presented before, the low $\mathrm{D} / \mathrm{P}$ value indicates an open formation where trees and shrubs are scarce, but more abundant than for the Holocene sample. The low $I_{\mathrm{ph}}$ value $(23 \%)$ indicates the dominance of Panicoideae grasses, and hence suggests humid local and/or regional conditions. The associated chloridoid morphotype, in lower proportion than in modern samples, may be related to local development of Chloridoideae grasses or to Phragmites. High $I_{\mathrm{c}}$ value $(59 \%)$ suggests that Pooideae grasses or Sporobolus supplied the phytolith assemblage of the Pleistocene sample. It is unlikely to consider that Pooideae grasses could have developed at $500 \mathrm{~m}$ of altitude during the Pleistocene, however, they may have occurred in the highlands, and contributed as regional source of pooid phytoliths.

Finally, the combination of remarkably low $I_{\mathrm{ph}}$ and high $I_{\mathrm{c}}$ values for the Pleistocene sample may be interpreted as attesting two kinds of environments: (1) riparian vegetation developed under suitable edaphic conditions and constituted of warmseason $\mathrm{C} 4$ grasses which requires high available soil moisture, such as Panicoideae, Phragmites and Sporobolus; and (2) grassland, adapted to humid climatic conditions in the lowlands, constituted of C4 grasses among which Panicoideae were dominant. C3-Pooideae grasses would have occurred in the highlands. In both hypotheses, the $\mathrm{D} / \mathrm{P}$ index is consistent and suggests scarce trees and shrubs.

\section{Conclusion}

Modern soils, Holocene and Pleistocene sediments from the Middle Awash paleoanthropological site contain well-preserved phytolith assemblages. Their different composition evidence that translocation from surface soil to geological layers is not important in the study area. Therefore, phytolith assemblages are valid tools for investigating past environments.

This study demonstrates that modern phytolith assemblages enable the differentiation of subdesertic steppe from wooded riparian forest, and characterize the composition of the C4-grass associations. Moreover, they record local as well as regional vegetation.

The phytolith assemblage of the Holocene sample records C4-Chloridoideae grassland close to the modern subdesertic shrub steppe, where C3-Pooideae grasses would similarly have covered the highlands. The phytolith assemblage of the Pleistocene sediment indicates an open grassland with more trees and shrubs, developed under humid edaphic conditions or under climate more humid than today. Remarkably, C3-Pooideae grasses are more abundant in the fossil than in the modern samples. The most probable hypothesis is that this might evidence stronger wind or runoff under wetter climatic conditions in the past. Further studies on modern phytolith assemblages are strongly needed to improve the calibration of indices against the modern vegetation and hence improve the validity of phytolith assemblages to reconstruct 
paleoenvironments notably for paleoanthropological sites, abundant in the Ethiopian Rift Valley.

\section{Acknowledgements}

This study was done at CEREGE, Aix-en-Provence, in the framework of D. Barboni's DEA 'Géosciences de l'Environnement'. Our greatest thanks are due to Professor T. White, Professor G. WoldeGabriel, and Professor B. Asfaw, leaders of the Middle Awash Research Project for encouraging this initiative and for their constructive criticism. Thanks to A. Brooks and J. Yellen for sampling Pleistocene strata and to H. Gilbert for cartographic assistance. The National Science Foundation (SBR-9318698, FD95-12534), the Los Alamos National Laboratory, Institute for Geophysics and Geoplanetary Sciences Campus-Laboratory Collaborations Program, and the France-Berkeley Fund supported the Middle Awash Research. Thanks to the Ethiopian Ministry of Information and Culture, Center for Research and Conservation of the Cultural Heritage and the National Museum of Ethiopia for permission and assistance. Thanks to the Afar people of the Middle Awash. Dr. Susan Mulholland and Dr. Glenn Fredlund reviewed the manuscript; their comments contributed considerably to the final draft.

\section{References}

Alexandre, A., Meunier, J.D., Lezine, A.M., Vincens, A., Schwartz, D., 1997. Phytoliths: indicators of grassland dynamics during the late Holocene in intertropical Africa. Palaeogeogr., Palaeoclimatol., Palaeoecol. 136, 213-229.

Bartolome, J.W., Klukkert, S.E., Parry, S.E., 1986. Opal phytoliths as evidence for displacement of native Californian grassland. Madrono 33 (3), 217-222.

Bonnefille, R., 1995. A reassessment of the Plio-Pleistocene pollen records of East Africa. In: Vrba, E.S., Denton, G.H., Partridge, T.C., Burckle, L.H. (Eds.), Paleoclimate and Evolution, with Emphasis on Human Origins. Yale University Press, New Haven, CT, pp. 299-310.

Bonnefille, R., Vincent, A., Buchet, G., 1987. Palynology, stratigraphy and palaeoenvironment of a Pliocene hominid site (2.93.3 My) at Hadar, Ethiopia. Palaeogeogr., Palaeoclimatol., Palaeoecol. 60, 249-281.

Bonnefille, R., Buchet, G., Friis, I., Kelbessa, E., Mohamed, M.U., 1993. Modern pollen rain on an altitudinal range of forests and woodlands in South West Ethiopia. Opera Bot.
121, 71-84.

Bozarth, S.R., 1992. Classification of opal phytoliths formed in selected Dicotyledons native to the Great Plains. In: Rapp, G., Mulholland, S.C. (Eds.), Phytolith Systematics. Plenum Press, New York and London, pp. 193-214.

Brown, D.A., 1984. Prospects and limits of a phytolith key for grasses in the central United States. J. Archaeol. Sci. 11, 345368.

Brown, W.V., 1977. The Kranz syndrome and its subtypes in grass systematics. Mem. Torrey Bot. Club 23, 1-97.

Clark, J.S., 1988. Particle motion and the theory of charcoal analysis: source area, transport, deposition, and sampling. Quat. Res. 30, 67-80.

Delliquadri, L.M., 1958. A contribution to the climate of Ethiopia (including the Somalilands). Ph.D. Thesis, Clark Univ., $151 \mathrm{pp}$.

Diester-Haas, L., Schrader, H.J., Thiede, J., 1973. Sedimentological and paleoclimatological investigations of two pelagic ooze cores off Cape Barbas, North-West Africa. 'Meteor' Forschungs-Ergeb. Reihe C 16, 19-66.

Ellis, R.P., 1979. A procedure for standardizing comparative leaf anatomy in the Poaceae. II; The epidermis as seen in surface view. Bothalia 12 (4), 641-671.

F.A.O., 1965. Report on survey of Awash River basin. United Nations, Rome, Vol. 1., 176 pp.

Fisher, R.F., Newell Bourn, C., Fisher, W.F., 1995. Opal phytoliths as an indicator of the floristics of prehistoric grasslands. Geoderma 68, 243-255.

Fredlund, G.G., Tieszen, L.L., 1994. Modern phytolith assemblages from the North American Great Plains. J. Biogeogr. 21, 321-335.

Fredlund, G.G., Tieszen, L.L., 1997. Phytolith and carbon isotope evidence for late Quaternary vegetation and climate change in the southern Black Hills, South Dakota. Quat. Res. 47, 206-217.

Fredlund, G.G., Johnson, W.C., Dort Jr., W., 1985. A preliminary analysis of opal phytoliths from the Eustis Ash Pit, Frontier County, Nebraska. Inst. Tertiary-Quaternary Stud.-Inst. TER-QUA Stud. Symp. Ser. 1, 147-162.

Friis, I., 1986. The forest vegetation of Ethiopia. Acta Univ. Symb. Bot. Upssala 26 (2), 31-47.

Geis, J.W., 1973. Biogenic silica in selected species of deciduous angiosperms. Soil Sci. 116 (2), 113-119.

Gillett, J.B., 1941. The plant formation of Western British Somaliland and the Harar Province of Abyssinia. Kew Bull. 1941 (2), 37-199.

Gilliland, H.B., 1952. The vegetation of Eastern British Somaliland. J. Ecol. 40 (1), 91-124.

Jones, J.B., Segnit, E.R., 1969. Water in the sphere-type opal. Mineral. Mag. 37, 357-361.

Kelly, E.F., 1990. Methods for extracting opal phytoliths from soil and plant material. Intern. Rep., Dep. Agron., Colorado State Univ., Fort Collins, CO, 10 pp.

Kurman, M.H., 1985. An opal phytolith and palynomorph study of extant and fossil soils in Kansas (USA). Palaeogeogr., Palaeoclimatol., Palaeoecol. 49, 217-235. 
Laroche, J., 1976. La silice et les plantes supérieures. Rev. Cytol. Biol. Vég. 40, 15-45.

Le Cohu, M.-C., 1973. Examen au Microscope Electronique à Balayage des cônes de silice chez les Cypéracées. C. R. Acad. Sci. Paris 277, 1301-1303.

Livingstone, D.A., Clayton, W.D., 1980. An altitudinal cline in tropical African grass floras and its paleoecological significance. Quat. Res. 13, 392-402.

Menaut, J.C., 1983. The vegetation of African savannas. In: Bourlière, F. (Ed.), Tropical Savannas. Ecosystems of the World, 13. Elsevier, Amsterdam.

Metcalfe, C.R., 1960. Anatomy of the Monocotyledons. I. Gramineae. Clarendon Press, Oxford.

Mulholland, S.C., 1986. Classification of grass silica phytoliths. In: Rovner, I. (Ed.), Plant Opal Phytolith Analysis in Archaeology and Paleoecology. Proc. 1984 Phytolith Research Workshop, Phytolitharien, Occas. Pap. 1, Raleigh, NC, pp. 41-52.

Mulholland, S.C., 1989. Phytolith shape frequencies in North Dakota grasses: a comparison to general patterns. J. Archaeol. Sci. 16, 489-511.

Mulholland, S.C., Rapp Jr., G., 1992. A morphological classification of grass silica-bodies. In: Rapp, G., Mulholland, S.C. (Eds.), Phytolith Systematics. Emerg. Iss. Adv. Archaeol. Mus. Sci. 1, 65-89.

Ollendorf, A.L., 1987. Archeological implications of a phytolith study at Tel Miqne (Ekron), Israel. J. Field Archaeol. 14, 453463.

Ollendorf, A.L., Mulholland, S.C., Rapp Jr., G., 1988. Phytolith analysis as a means of plant identification: Arundo donax and Phragmites communis. Ann. Bot. 61, 209-214.

Palmer, P.G., Gerbeth-Jones, S., 1986. A scanning electron microscope survey of the epidermis of East African grasses, IV. Smithson. Contrib. Bot. 62, 120 pp.

Palmer, P.G., Tucker, A.E., 1981. A scanning electron microscope survey of the epidermis of East African grasses, I. Smithson. Contrib. Bot. 49, 84 pp.

Palmer, P.G., Tucker, A.E., 1983. A scanning electron microscope survey of the epidermis of East African grasses, II. Smithson. Contrib. Bot. 53, 72 pp.

Palmer, P.G., Gerbeth-Jones, S., Hutchinson, S., 1985. A scanning electron microscope survey of the epidermis of East African grasses, III. Smithson. Contrib. Bot. 55, 136 pp.
Piperno, D.R., 1988. Phytolith Analysis. An Archaeological and Geological Perspective. Academic Press, New York, NY, 280 pp.

Rovner, I., 1971. Potential of opal phytoliths for use in paleoecological reconstruction. Quat. Res. 1, 343-359.

Scurfield, G., Anderson, C.A., Segnit, E.R., 1974. Silica in woody stems. Aust. J. Bot. 22, 211-229.

Sermolli, P., 1957. Una carta geobotanica dell'Africa Orientale (Eritrea, Etiopia, Somalia). Webbia XIII (1), 15-132.

Smith, B.N., Brown, W.V., 1973. The Kranz syndrome in the Gramineae as indicated by carbon isotopic ratios. Am. J. Bot. 60, 505-513.

Tieszen, L.L., Senyimba, M.M., Imbamba, S.K., Troughton, J.H., 1979. The distribution of C3 and C4 grasses and carbon isotope discrimination along an altitudinal and moisture gradient in Kenya. Oecologia 37, 337-350.

Twiss, P.C., 1980. Opal phytoliths as indicators of C3 and C4 grasses. Geol. Soc. Am. Abstr. 12, 17.

Twiss, P.C., 1983. Dust deposition and opal phytoliths in the Great Plains. Trans. Nebr. Acad. Sci. 11, 73-82.

Twiss, P.C., 1987. Grass-opal phytoliths as climatic indicators of the Great Plains Pleistocene. In: Johnson, W.C. (Eds.), Quaternary Environments of Kansas. Kans. Geol. Surv. Guidebook Ser. 5, 179-188.

Twiss, P.C., 1992. Predicted world distribution of C3 and C4 grass phytoliths. In: Rapp, G., Mulholland, S.C. (Eds.), Phytolith Systematics. Emerg. Iss. Adv. Archaeol. Mus. Sci. 1, 113-128.

Twiss, P.C., Suess, E., Smith, R.M., 1969. Morphology classification of grass phytoliths. Proc. Soil Sci. Soc. Am. 33, 109115.

Watson, L., Clifford, H.T., Dallwitz, M.J., 1985. The classification of Poaceae: subfamilies and supertribes. Aust. J. Bot. 33, 433-484.

Welle, B.J.H., 1976. On the occurrence of the silica grains in the secondary xylem of the Chrysobalanaceae. Iawa Bull. 1976 (2), 19-29.

White, F., 1983. The vegetation of Africa. A descriptive memoir to accompany the Unesco/AETFAT/UNSO vegetation map of Africa. Nat. Resour. Res. 20, UNESCO, Paris, pp. 356.

White, T., Suwa, G., Asfaw, B., 1994. Australopithecus ramidus, a new species of early hominid from Aramis, Ethiopia. Nature 371, 306-312. 